\title{
Internships Abroad: A Career Booster for German Students
}

\author{
Pascal Cromm, Aalen University of Applied Sciences, Germany \\ Karin Kadow, Aalen University of Applied Sciences, Germany
}

BESIDES THE FUNDAMENTAL REQUIREMENT of companies regarding young graduates to possess a very sound theoretical knowledge related to their degree programme, soft skills competences, and of course broad foreign language skills, solid practical experiences are considered to be a "must" too. In the German higher education system, the acquisition of practical experience is firmly anchored in study and examination regulations as far as so called "universities of applied sciences" are concerned. Compared to traditional universities, which focus more on fundamental research, universities of applied sciences - which focus more on applied research, cooperate very closely with industry, and actually provide the German labour market with almost $60 \%$ of the engineering and business graduates - are very practice oriented; this is reflected among others in the fact that there is a mandatory internship for all degree programmes, generally in the $5^{\text {th }}$ semester. If in addition this internship takes place abroad, it shows that the student not only has proven practical experience but also possesses soft skills competences including intercultural competences and foreign language skills.

There are many positive aspects on both sides when it comes to a practical semester. A recent article on the value of internships in the preparation) the cooperation proves to be valuable for both Brose Company and the students: The company gets to know promising young academics. The students, on the other hand, get the opportunity to enhance their professional and intercultural skills, thus gaining 'vocational fitness' for a future international career," states Ina Laiadhi (2011).

It is the responsibility of individual students, though, through meaningful applications, to find a suitable internship that matches the content and the requirements of their study programme and with it contributes to a high learning effect. Students find support through the professors of their department and the international office of their university. The professors, who at universities of applied sciences appraise and evaluate the students'internship reports following the internship, all possess longstanding industrial experience in their field of specialisation and thus function as door openers for the students through their own extensive professional networks.

Practical experience gained abroad has an additional value. International experience on the CV is held in particularly high esteem by $H R$, as it shows that a candidate can adapt to new circumstances and changing work situations, is flexible, and has excellent language skills. The Trendence Institute that focuses its studies on Germany's Top 100 Employers notes that in

daily national newspaper Die Welt (The World; Maaß, 2014) states that companies give away potential if they do not tie talented interns to the company. Nurturing them becomes especially important in order to recruit the rare professionals with a high degree of loyalty. Conversely, students get opportunities from doing an internship if companies would be interested in a long-term commitment. In these respects the mediator role of universities is of primary importance.

Companies abroad particularly appreciate the value of cooperation with German universities in that respect, as confirmed by the automotive supplier Brose: "The cooperation between the automotive supplier Brose's Spanish production site and Aalen University is a success story: Highly qualified, motivated and committed young academics are completing six-month work placements at Brose's Spanish location in Sta. Margarida for years. Thanks to the professional work of Aalen University's International Office (ranging from selection to language the case of successful time abroad, HR can make their own assumptions about having a good deal of initiative, independence, and increased teamwork, which are "skills that every business wants from its employees." A company like Bosch emphasises in this respect particularly on "the acquisition of social skills such as intercultural knowledge, mobility and readiness for missions in other countries," confirms Nicolet Eglseder (2014). Such qualities are particularly encouraged by Aalen University in its students and thus various study programmes such as International Business Studies or International Sales Management \& Technology mandate internships abroad.

As German industry relies heavily on its high export share, companies know about the importance of obtaining highly profiled graduates from universities who are able to perform on the international business floor. Cooperation with universities is therefore very developed at various levels. Besides their structural presence on boards like the board 
of governors, the university council, or technical boards related to the development of study programme syllabuses, company representatives also teach in their field of expertise, especially at universities of applied sciences.

Indeed, especially at universities of applied sciences students are very well prepared by a variety of events during their studies for their professional career. Bachelor's degrees prepare them for direct employment on the labour market; practical elements such as lab work, projects, and group assignments, as well as the compulsory internship, are introduced into the syllabuses; also, companies are regularly invited to the university to give speeches on cutting-edge themes and to participate in recruiting fairs. Very often the bachelor's theses are carried out in companies or with support of companies, and students tie their respective links to obtain such final projects within the period of their internship. The transition from the "world of learning" to the "world of working" becomes thus very smooth for students at German universities of applied sciences.

Many graduates owe their entry into particularly good jobs with international companies to their internships abroad. The skills acquired abroad are important not only in foreign assignments, but also with international colleagues within Germany. It is a common goal of higher education and industry in Germany to equip students with comprehensive tools serving all aspects of the requirements for young graduates. This includes not only the knowledge but also the strengths of personality and a sense of responsibility and a positive understanding of both their own and foreign cultures.

\section{References}

Maaß, S. 2014. Die Welt. Dated June 28, 2014, http://www.welt.de/ wirtschaft/karriere/bildung/article117094779/Kontaktpflegezu-ehemaligen-Praktikanten-lohnt-sich.html.

Laiadhi, I. 2011. National Agency for EU Higher Education Cooperation, German Academic Exchange Service DAAD, Bonn, Germany

Eglseder, N. 2014. www.deutschlands100.de Top-Arbeitgeber zeigen Profil, trendence Institut GmbH, Berlin.
Pascal Cromm (Pascal.Cromm@htw-aalen.de) is the director of international relations of Aalen University of Applied Sciences, institutional Bologna and Erasmus coordinator and was a member of the Board of Governors of the University. He has been project leader for Aalen University in a number of European funded projects within the lifelong learning program, is a Fulbright alumnus of the educational experts program and possesses altogether over 20 years of experience in the internationalization of higher education.

Karin Kadow is a senior international relations officer at Aalen University of Applied Sciences in Germany. Karin is counsellor for outgoing students who intend to do their internships abroad. Karin started her career as a banker and possesses many years of industrial work experience including on the international level for companies in the USA and Sweden. Her experience in also coaching job-seekers complements her know-how to successfully provide students with competent advice. 